\title{
Bariatrik Cerrahi Sonrasında Lityum Düzeyi Etkilenir mi?
}

\author{
Ömercan TOPALOĞLU ๑凶 \\ Kocaeli Derince Eğitim ve Araştırma Hastanesi, Endokrinoloji Kliniği, Kocaeli, Türkiye \\ Bu olgu, 27-28 Eylül 2019'da Zonguldak’ta düzenlenen "IV. Zonguldak Endokrin Günleri” Kongresi’nde Sözlü Bildiri olarak sunulmuştur.
}

Bu makaleye yapılacak atıf: Topaloğlu Ö. Bariatrik Cerrahi Sonrasında Lityum Düzeyi Etkilenir mi? Türk Diyab Obez 2020;2: 197-200.

ÖZ

Giriş: Kronik hastalık sebebiyle ilaç kullanımı olan hastalarda, bariatrik cerrahi sonrasında ilaç dozları ayarlanmalıdır. Bariatrik cerrahi sonrası oral alınan ilaçların farmakokinetiği ile ilgili çalışmalar sınırlıdır. Biz de bariatrik cerrahi sonrasında lityum kullanımına devam etmesi gereken genç bipolar erkek obez hastamızı sunacă̆ız.

Olgu: 26 yaşında erkek hasta son 1 yılda 20 kilo alımı sebebiyle başvurdu. Hasta 2 yıldır bipolar bozukluk (BPB) tanısıyla, risperidon 2 mg 1x1 tablet ve lityum 1x3 kapsül kullanıyordu. Astım tanısı olan hastanın düzenli inhaler kullanımı yoktu. Fizik bakıda; vücut ağırlı̆̆ı: $195 \mathrm{~kg}$, boy: $184 \mathrm{~cm}$, vücut kütle indeksi: $57.5 \mathrm{~kg} / \mathrm{m}^{2}$ ve vital bulgular stabil saptandı. Akciğer muayenesinde ronkuslar saptandı; diğer sistem muayeneleri normal sinırlardaydı. Laboratuar bulgularında; glukoz: $480 \mathrm{mg} / \mathrm{dL}$, kreatinin: $0.9 \mathrm{mg} / \mathrm{dL}, \mathrm{ALT}$ : $65 \mathrm{U} / \mathrm{L}$, AST: $28 \mathrm{U} / \mathrm{L}, \mathrm{Na}: 143 \mathrm{mmol} / \mathrm{L}, \mathrm{K}: 4 \mathrm{mmol} / \mathrm{L}, \mathrm{HDL}: 26 \mathrm{mg} / \mathrm{dL}, \mathrm{LDL}: 165 \mathrm{mg} / \mathrm{dL}$, Trigliserid: $200 \mathrm{mg} / \mathrm{dL}$, HbA1c: \%8.5 saptandi. Tip 2 diyabet tanısıyla, eksenatid 5 mcg 2x1 subkütan ve metformin $1000 \mathrm{mg} 2 \mathrm{x} 1$ tb başlandı ve kan şekeri regülasyonu sağlandı. Psikiyatri tarafından değerlendirilen hasta BPB açısından stabil seyretti ve serum lityum düzeyi: $0.5 \mathrm{mEq} / \mathrm{L}$ saptandı. Bariatrik cerrahi konseyinde değerlendirildi ve laparoskopik Roux-n-Y gastrik bypass (RYGB) cerrahisi planland. Postoperatif pulmoner komplikasyonları azaltmak için perioperatif beta2 agonist inhaler tedavi başlandı. RYGB uygulanan hastaya postoperatif dönemde metformin veya eksenatid verilmedi. Bariatrik cerrahi diyeti verilen hastanın kan şekeri regülasyonu antidiyabetik bir ajana ihtiyaç duyulmadan sağlandı. Hasta postoperatif dönemde lityum ve risperidonu tolere edemedi ve bu sebeple hastaya sublingual olanzapin $10 \mathrm{mg}$ başlandi. Daha sonra postoperatif 1.ayda risperidon im $25 \mathrm{mg} 2$ haftada bir uygulanmaya başlandı. İntolerans sebebiyle postoperatif 6 . aya kadar lityum verilmedi. Postoperatif 6. ayda lityum 1x1 kapsül başlandı, doz haftada bir tedricen 1x3 kapsüle çıkıldı. Tedavinin 1. ayında bakılan lityum düzeyi $0.21 \mathrm{mEq} / \mathrm{L}, 6$. ayında $0.129 \mathrm{mEq} / \mathrm{L}$ ölçüldü. Efektif lityum düzeyi sağlanamadı.

Sonuç: Bulantı sebebiyle postoperatif lityum kullanımı zorlaşmaktadır. Hastamızda postoperatif 6 . aydan sonra lityum düzenli verilebildi ancak serum lityum düzeyi referans aralığına ulaşmadı. BPB’de bariatrik cerrahi sonrasında lityum kullanımı ile ilgili geniş çalışmalara ihtiyaç vardır.

Anahtar Sözcükler: Bariatrik cerrahi, Lityum, Lityum düzeyi, Obezite, Bipolar bozukluk

\section{May the Level of Lithium be Affected After Bariatric Surgery?}

\begin{abstract}
Introduction: In patients with medication for chronic illnesses, using medications for chronic illnesses, the doses of drugs should be adjusted before bariatric surgery. Studies investigating the pharmacokinetics of the oral drugs used after bariatric surgery are limited. We will present a young bipolar male obese patient who should continue to use lithium after bariatric surgery.

Case: Twenty-six-year-old male was applied to our clinics with the complaint of weight gain of $20 \mathrm{~kg}$ in a year. This patient was reported to have taken risperidone $2 \mathrm{mg}$ tb $1 \mathrm{x} 1$ and lithium capsule $1 \mathrm{x} 3$ due to bipolar disorder (BPD). Also, the patient who had previously been diagnosed with asthma did not take any inhaler medication for it. On physical examination; body weight was $195 \mathrm{~kg}$, height $184 \mathrm{~cm}$, body mass index $57.5 \mathrm{~kg} / \mathrm{m}^{2}$ and vital findings were stable. Respiratory examination revealed rhonchus, and the examination of other organ systems was unremarkable. Laboratory evaluation revealed that glucose was $480 \mathrm{mg} / \mathrm{dL}$, creatinine: $0.9 \mathrm{mg} / \mathrm{dL}$, ALT: $65 \mathrm{U} / \mathrm{L}$, AST: 28
\end{abstract}

ORCID: Ömercan Topaloğlu / 0000-0003-3703-416X 
U/L, Na: 143 mmol/L, K: 4 mmol/L, HDL: 26 mg/dL, LDL: 165 mg/dL, Triglyceride: $200 \mathrm{mg} / \mathrm{dL}$, HbA1c: 8.5\%.With the diagnosis of type 2 diabetes, exenatide $5 \mathrm{mcg} 2 \mathrm{x} 1$ subcutaneous and metformin $1000 \mathrm{mg} 2 \mathrm{x} 1 \mathrm{tb}$ were given, and hyperglycemia was regulated.The patient was examined by psychiatry, and BPD was found to be stable. Serum level of lithium was $0.5 \mathrm{mEq} / \mathrm{L}$. Laparoscopic Roux-n-Y gastric bypass (RYGB) surgery was planned after bariatric surgery council. To decrease postoperative pulmonary complications, perioperative inhaler beta2 agonist was given. Metformin and exenatide was discontinued after RYGB. The patient was given bariatric surgery diet, but he could not tolerate oral lithium or risperidone. Sublingual olanzapin $10 \mathrm{mg}$ was given. Later, in postoperative $1^{\text {st }}$ month, risperidon im $25 \mathrm{mg}$ each 2 weeks was initiated to be taken in every 2 weeks. Because of intolerance, it was not given until postoperative $6^{\text {th }}$ month. Lithium capsule $1 \times 1$ was started at postoperative $6^{\text {th }}$ month, and increased gradually up to $1 \times 3$ capsule. The level of lithium was 0.21 and $0.129 \mathrm{mEq} / \mathrm{L}$, in the first and $6^{\text {th }}$ month of the initiation of lithium, respectively. Effective level could not be achieved.

Conclusion: Due to nausea, postoperative use of lithium may become difficult. Lithium could be given to our patient regularly after $6^{\text {th }}$ postoperative month, but the reference level could not be achieved. Large studies investigating the use of lithium in patients with BPD after bariatric surgery will clarify this issue.

Key Words: Bariatric surgery, Lithium, Lithium level, Obesity, Bipolar disorder

\section{GİRIŞ}

Obezite dünya genelinde giderek artan bir problem olarak karşımıza çıkmaktadır. Bariatrik cerrahi, vücut kütle indeksi (VKİ) $\geq 40 \mathrm{~kg} / \mathrm{m}^{2}$ olan hastalarda uzun süreli kalıcı kilo kaybını sağlayabilen tek yöntemdir (1). Kronik hastalık sebebiyle ilaç kullanımı olan hastalarda, postoperatif dönemde kullanılacak ilaçlar ve dozları preoperatif ve postoperatif dönemde ayarlanmalıdır. Ancak bariatrik cerrahi sonrasında, birçok ilacın emilimi değiştiği için preoperatif ilaç doz ayarlaması zor olabilmektedir. Bariatrik cerrahi sonrası oral alınan ilaçların farmakokinetiği ile ilgili çalışmalar sınırlıdır (2-5). Roux-n-Y gastrik bypass (RYGB) cerrahisi sonrasında fonksiyonel bağırsak uzunluğu azaldığg 1 için ilaç emilimi azalabilmektedir (2). Ancak, kalan bağırsak segmentinde adaptif olarak ortaya çıkan mukozal hipertrofi emilim kapasitesini artırmaktadır. RYGB'nin ve diğer bariatrik cerrahi prosedürlerinin, farklı ilaç gruplarının emilimi üzerindeki net etkileri henüz açığa kavuşmamıştır.

Bariatrik cerrahi sonrasinda antidepresan kullanımı ve etkinliğine ilişskin çeşitli çalışmalar vardır (6,7). Ancak, RYGB'nin lityum kullanımı üzerindeki etkisine ilişkin kapsamlı çalışmalar mevcut değildir. Literatürde, RYGB sonrasında lityum intoksikasyonu geliştiğini gösteren çeşitli olgu raporları yayınlanmıştır (8-13). Biz de bariatrik cerrahi sonrasında lityum kullanımına devam etmesi gereken genç bipolar erkek obez hastamızı yayınlıyoruz.

\section{OLGU}

Yirmi altı yaşında erkek hasta vücut ağırlığında son bir yılda $20 \mathrm{~kg}$ artış sebebiyle başvurdu. Hasta 2 yıldır bipolar bozukluk (BPB) tanısıla, risperidon $2 \mathrm{mg} 1 \mathrm{x} 1$ tablet/gün ve lityum 1x3 kapsül/gün kullanıyordu. Astım tanısı olan hastanın düzenli inhaler kullanımı yoktu.

Fizik bakıda; vücut ağırlığı:195 kg, boy: $184 \mathrm{~cm}$, vücut kütle indeksi: $57.5 \mathrm{~kg} / \mathrm{m}^{2}$ olarak ölçüldü.
Vital bulgular stabil saptandı. Hastanın bilinci açıktı, kooperasyon ve oryantasyonu tamdi. Akciğer muayenesinde ronkuslar saptandı; kardiyovasküler ve gastrointestinal sistem muayeneleri normal sinırlardaydı. Nörolojik muayenesi normaldi.

Laboratuvar bulgularında; glukoz: $480 \mathrm{mg} / \mathrm{dL}$, kreatinin: 0.9 mg/dL, ALT: 65 U/L, AST: 28 U/L, Na: 143 mmol/L, K: 4 mmol/L, Ca: $9 \mathrm{mg} / \mathrm{dL}, \mathrm{P}: 3.5 \mathrm{mg} / \mathrm{dL}$, total kolesterol: 231 mg/dL, HDL: 26 mg/dL, LDL: $165 \mathrm{mg} / \mathrm{dL}$, trigliserid: 200 $\mathrm{mg} / \mathrm{dL}, \mathrm{HbA1c}: \%$ 8.5, beyaz küre: $8900 / \mathrm{mm}^{3}$, hemoglobin: $13.5 \mathrm{~g} / \mathrm{dL}$ ve trombosit: $270.000 / \mathrm{mm}^{3}$ saptand 1 .

Hastanın kan şekeri regülasyonu önce intravenöz regüler insülin infüzyonu daha sonra subkütan regüler ve NPH insülin (Nötral Protamin Hagedorn insülin) uygulamasıyla sağlandı. Hasta diyet programına alındı ve tip 2 diyabet tanisiyla hastaya eksenatid $5 \mathrm{mcg} 2 \mathrm{xl}$ subkütan ve metformin 1000 mg 2x1 tb başlandı. Bu tedaviyle kan şekeri regülasyonu sağlandı.

Psikiyatri tarafından değerlendirilen hastanın BPB açısından stabil seyrettiği tespit edildi. Hastanın serum lityum düzeyi: $0.5 \mathrm{mEq} / \mathrm{L}$ ölçüldü. Hasta bariatrik cerrahi konseyinde değerlendirildi ve laparoskopik Roux-n-Y gastrik bypass (RYGB) cerrahisi planlandı. Göğüs hastalıkları ile konsülte edilen hastaya postoperatif pulmoner komplikasyonları azaltmak için perioperatif beta2 agonist inhaler tedavi başlandı.

RYGB uygulanan hastaya postoperatif dönemde metformin veya eksenatid verilmedi. Düzenli kapiller ve venöz kan şekeri ölçümü yapılan hastanın postoperatif dönemde hiperglisemisi olmadi. Bariatrik cerrahi konusunda özelleşmiş diyetisyen ile konuşularak bariatrik cerrahi diyeti başland. Takiplerine göre postoperatif diyeti revize edildi. Diyetine tam olarak uyum gösteren hasta lityum ve risperidon tedavisini tolere edemedi. Hastaya sublingual olanzapin 
$10 \mathrm{mg}$ başlandi. Daha sonra postoperatif 1.ayda risperidon im $25 \mathrm{mg} 2$ haftada bir uygulanmaya başlandı. Ara ara lityum denenen hastada bulantı ve kusma gelişmesi sebebiyle postoperatif 6 . aya kadar lityum verilemedi.

Postoperatif 6. ayda hasta bariatrik cerrahi öncesine göre 55 kg kaybetti, vücut ağırlığı: 140 kg ölçüldü. Hastaya lityum 1x1 kapsül/gün dozunda tekrar denendi ve doz haftada bir tedricen $1 \times 3$ kapsül/gün dozuna çıkıldı. Tedavinin 1. ayında bakılan lityum düzeyi $0.21 \mathrm{mEq} / \mathrm{L}, 6$. ayında $0.129 \mathrm{mEq} / \mathrm{L}$ ölçüldü. Hastada efektif lityum düzeyi sağlanamadı. Ancak antipsikotik kullanımı düzenli olan hastada postoperatif dönemde mani veya depresyon atağ 1 izlenmedi. Psikiyatri bölümü ile görüşülerek hastanın takibine karar verildi, lityum dozu artırılmadı (Şekil 1).

\section{TARTIȘMA}

BPB tanılı hastalar, bariatrik cerrahi öncesinde psikiyatri ile konsülte edilmeli ve postoperatif dönemde kullanılacak ilaçlar düzenlenmelidir. Postoperatif ruhsal semptomların takibi yapılmalı ve gerektiğinde anksiyolitik veya parenteral antipsikotikler ile müdâhale edilmelidir.

Lityumun önemli yan etkilerinden biri bulantıdır. Bariatrik cerrahi sonrasında bulantı ve kusma sebebiyle spesifik diyetler bile zor tolere edilmektedir. Bu sebeple postoperatif lityum kullanımı zorlaşmaktadır. RYGB sonrası efektif barsak uzunluğunun azalması sebebiyle lityum emiliminin azalabileceği ve bu sebeple efektif düzeye ulaşmanın zor olacağı düşünülebilir. Ancak çeşitli olgu raporlarında RYGB veya sleeve gastrektomi sonrasında lityum intoksikasyonu gösterilmiştir (8-13). Adaptif olarak ortaya çıan mukozal hipertrofi lityum absorpsiyonunun artmasına yol açmıș olabilir. Bizim hastamızda lityum intoksikasyonu gelişmemekle birlikte, efektif serum lityum düzeyine bile ulaşılamadı.

Literatürdeki olgu raporlarında lityum intoksikasyonu genellikle bariatrik cerrahiden sonraki ilk birkaç gün içinde meydana gelmiştir $(9,12)$. Aslında bariatrik cerrahi sonrası ilerleyen haftalarda kilo kaybı arttıkça, lityum dozu fazla gelebileceği için lityum intoksikasyonu beklenebilirdi. Bizim hastamızda, postoperatif dönemde birkaç defa lityum denenmesine rağmen bulantı, kusma ve intolerans sebebiyle postoperatif erken dönemde lityum verilemedi. Hastamızda postoperatif 6 . aydan sonra lityum düzenli verildi ancak serum lityum düzeyi normal referans aral1ğına ulaşamadı. Postoperatif erken dönemde absorpsiyon kapasitesinin arttığ düşünülürse, cerrahinin lityum farmakokinetiği üzerindeki net etkisinin lityum intoksikasyonu yönünde olmasını beklemek zor olmaz. Bariatrik cerrahi sonrasında, kilo kaybı arttıkça hem kilo kaybına bağlı hem de glomerüler filtrasyon hızının azalmasına bağlı lityum ihtiyacının azalması beklenir $(14,15)$. Ciddi kilo kaybının olduğu, kilo kaybına bağlı glomerüler filtrasyon hızının azaldığı ve mukozal absorpsiyon kapasitesinin arttığ düşünüldügünde, geç postoperatif dönemde de lityum intoksikasyonun gelişmesi öngörülebilir. Ancak hastamızda geç postoperatif dönemde, efektif lityum düzeyinin sağlanamaması lityum farmakokinetiğinin bariatrik cerrahi sonrasında zamanla değişebileceğine işaret eder.

Sonuç olarak, bariatrik cerrahi hastalarında postoperatif dönemde lityumun farmakokinetiği zamanla değişebilir. Farmakokinetikteki bu değişim, uygulanan bariatrik cer-

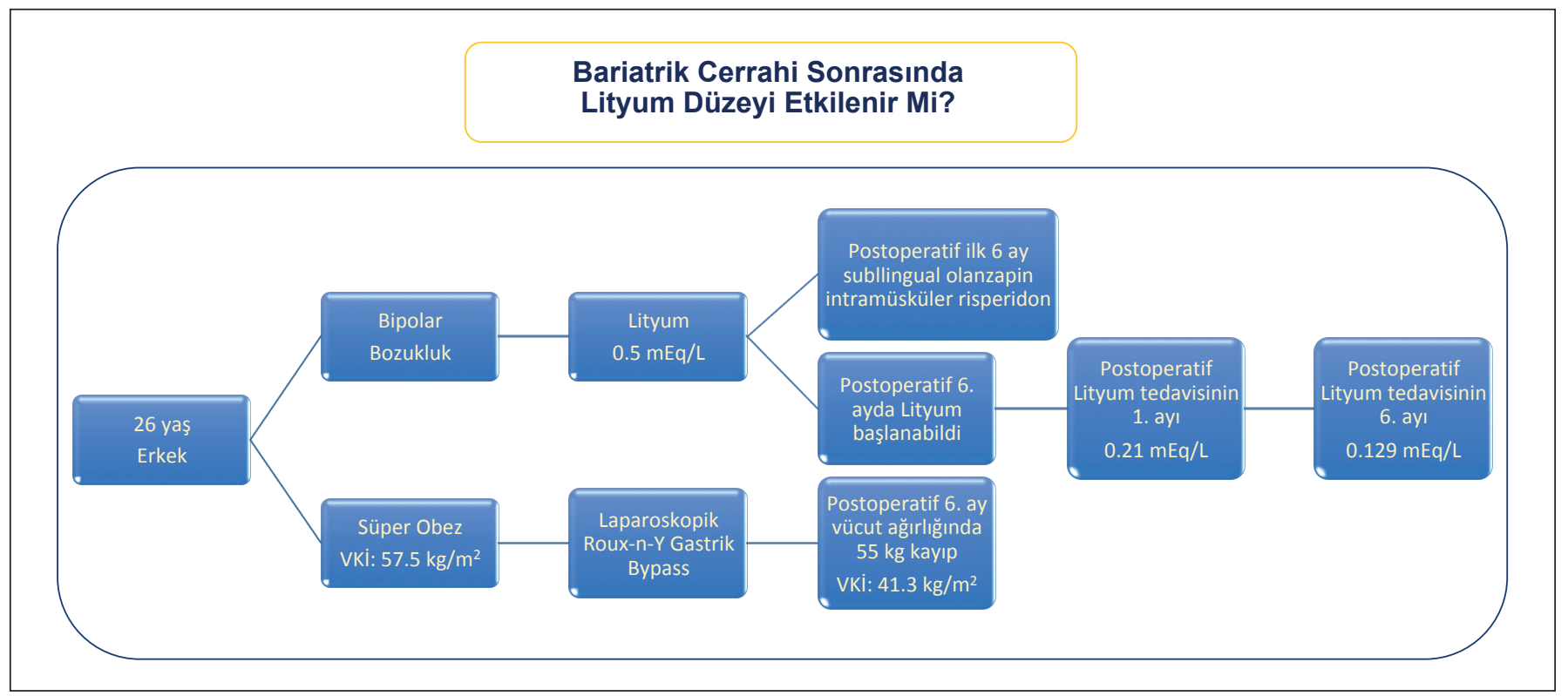

Şekil 1: Olgunun klinik seyri 
rahi yöntemine göre farklılık gösterir. Gastrektomi veya malabsorpsiyonun derecesi lityum farmakokinetiğindeki değişimde rol oynayabilir. BPB tanılı ve lityum kullanan hastaların preoperatif ve postoperatif uzun dönemde klinik bulgular ve serum lityum düzeyi ile takip edildiği geniş klinik çalışmalar, bariatrik cerrahi hastalarında lityum farmakokinetiğini daha net olarak ortaya koyacaktır.

\section{Etik Kurul Onayı}

Olgu sunumu için etik kurul oluru gerekmemiştir. Hastanın onamı alınmıștır.

\section{Çıkar Çatışması}

Yazar, hiçbir çıkar çatışması bulunmadığını beyan eder.

Finansal Destek

Tasarımında, veri toplanmasında veya yazımında finansal destek alınmamıștır.

\section{Yazarların Makaleye Katkı Beyanı}

Yazının fikri, tasarımı ve yazımı yazara aittir.

\section{Hakem Değerlendirmesi}

Kör hakemlik süreci sonrası yayınlanmaya uygun bulunmuş ve kabul edilmiștir.

\section{KAYNAKLAR}

1. Leff DR, Heath D. Surgery for obesity in adulthood. Br Med J. 2009;339:740-746.

2. Padwal R, Brocks D, Sharma AM. A systematic review of drug absorption following bariatric surgery and its theoretical complications. Obes Rev. 2010;11:41-50.

3. MacGregor AMC, Boggs L. Drug distribution in obesity and following bariatric surgery: A literature review. Obes Surg. 1996; 6:17-27.

4. Malone M. Altered drug disposition in obesity and after bariatric surgery. Nutr Clin Pract. 2003;18:131-135.
5. Miller AD, Smith KM. Medication and nutrient administration considerations after bariatric surgery. Am J Health Syst Pharm. 2006;63:1852-1857.

6. Yska JP, van der Meer DH, Dreijer AR, Eilander W, Apers JA, Emous M, Totté ER, Wilffert B, van Roon EN. Influence of bariatric surgery on the use of medication.. Eur J Clin Pharmacol. 2016;72(2):203-209.

7. Yska JP, van der Linde S, Tapper VV, Apers JA, Emous M, Totté ER, Wilffert B, van Roon EN. Influence of bariatric surgery on the use and pharmacokinetics of some major drug classes. Obes Surg. 2013;23(6):819-825.

8. Dahan A, Porat D, Azran C, Mualem Y, Sakran N, Abu-Abeid S. Lithium Toxicity with Severe Bradycardia Post Sleeve Gastrectomy: A Case Report and Review of the Literature. Obes Surg. 2019;29(2):735-738.

9. Niessen R, Sottiaux T, Schillaci A, Lejeune F. (Lithium toxicity after bariatric surgery). Rev Med Liege. 2018;73(2):82-87.

10. Wasserman B, Jiang W. Lithium Toxicity after Roux-en-Y Gastric Bypass is Not Just Limited to Perioperative Period. Psychosomatics. 2018;59(2):206.

11. Bingham KS, Thoma J, Hawa R, Sockalingam S. Perioperative Lithium Use in Bariatric Surgery: A Case Series and Literature Review. Psychosomatics. 2016;57(6):638-644.

12. Musfeldt D, Levinson A, Nykiel J, Carino G. Lithium toxicity after Roux-en-Y bariatric surgery. BMJ Case Rep. 2016;2016. pii: bcr2015214056.

13. Tripp AC. Lithium toxicity after Roux-en-Y gastric bypass surgery. J Clin Psychopharmacol. 2011;31(2):261-262.

14. Williams D. Lithium toxicity: Risk factors, monitoring, and management. 2014 (updated 1 November, 2014 11/6/2015). http://www.uspharmacist.com/continuing_education/ ceviewtest/lessonid/110716/.

15. Walsh K, Volling J. Lithium toxicity following Roux-en-Y gastric bypass. Bariatr Surg Pract Patient Care. 2014;9:77-80. 